\title{
Validation of logical models for the management of tuberculosis treatment
}

\author{
Validação de modelos lógicos para o manejo do tratamento da tuberculose \\ Validación de modelos lógicos para el manejo del tratamiento de la tuberculosis
}

\section{Shirley Ribeiro dos Santos Linhares' ORCID: 0000-0002-2202-8798 \\ Elisabete Pimenta Araújo Paz' ORCID: 0000-0002-1692-0253 \\ Gisela Cordeiro Pereira Cardoso" ORCID: 0000-0002-4014-0951}

'Universidade Federal do Rio de Janeiro. Rio de Janeiro, Rio de Janeiro, Brazil.

"Fundação Oswaldo Cruz. Rio de Janeiro, Rio de Janeiro, Brazil.

How to cite this article: Linhares SRS, Paz EPA, Cardoso GCP. Validation of logical models for the management of tuberculosis treatment. Rev Bras Enferm. 2020;73(Suppl 6):e20190812. doi: http://dx.doi.org/10.1590/0034-7167-2019-0812

Corresponding author: Shirley Ribeiro dos Santos Linhares E-mail: shirleyrslinhares@gmail.com

EDITOR IN CHIEF: Dulce Barbosa ASSOCIATE EDITOR: Hugo Fernandes

Submission: 03-13-2020

Approval: 07-04-2020

\begin{abstract}
Objectives: to describe the steps of validation of the logical models of the Directly Observed Treatment and the Information System of the Directly Observed Treatment Short-Course Strategy. Methods: methodological study carried out from February to June 2018, in two stages. The content of the items that make up the models was based on scientific evidence and submitted to the experts for content validation. The Content Validity Index was applied, accepting the value $\geq 0.80$. Results: the agreement, regarding its validity, was satisfactory in the 79 items analyzed. The logical models were considered valid with a Global Validity Index of 0.91 for the Directly Observed Treatment and 0.87 for the Information System. Conclusions: the logical models were considered valid in terms of content, being a useful and timely instrument to support managers in decision-making. Descriptors: Validation Study; Tuberculosis; Health Management; Health Evaluation; Health Services.
\end{abstract}

\section{RESUMO}

Objetivos: descrever as etapas de validação dos modelos lógicos do Tratamento Diretamente Observado e do Sistema de Informação da Estratégia Directly Observed Treatment Short-Course. Métodos: estudo metodológico realizado de fevereiro a junho de 2018, em duas etapas. $O$ conteúdo dos itens que compõem os modelos foi fundamentado em evidências científicas e submetido à apreciação de especialistas para validação de conteúdo. Aplicou-se o Índice de Validade de Conteúdo, aceitando-se o valor $\geq 0,80$. Resultados: a concordância, quanto $a ̀$ sua validade, foi satisfatória nos 79 itens analisados. Os modelos lógicos foram considerados válidos com Índice de Validade Global de 0,91 para o Tratamento Diretamente Observado e de 0,87 para o Sistema de Informação. Conclusões: os modelos lógicos foram considerados válidos quanto ao conteúdo, sendo um instrumento útil e oportuno para fundamentar os gestores na tomada de decisão

Descritores: Estudo de Validação; Tuberculose; Gestão em Saúde; Avaliação em Saúde; Serviços de Saúde.

\section{RESUMEN}

Objetivos: describir las etapas de validación de los modelos lógicos del Tratamiento Directamente Observado y del Sistema de Información de la Estrategia Directly Observed Treatment Short-Course. Métodos: estudio metodológico realizado de febrero a junio de 2018, en dos etapas. El contenido de los ítems que componen los modelos ha sido fundamentado en evidencias científicas y sometido a la apreciación de especialistas para validación de contenido. Se aplicó el Índice de Validez de Contenido, aceptándose el valor $\geq$ 0,80 . Resultados: la concordancia, cuanto a su validez, ha sido satisfactoria en los 79 ítems analizados. Los modelos lógicos han sido considerados válidos con Índice de Validez Global de 0,91 para el Tratamiento Directamente Observado y de 0,87 para el Sistema de Información. Conclusiones: los modelos lógicos han sido considerados válidos cuanto al contenido, siendo un instrumento útil y oportuno para fundamentar los gestores en la toma de decisión. Descriptores: Estudio de Validación; Tuberculosis; Gestión en Salud; Evaluación en Salud; Servicios de Salud. 


\section{INTRODUCTION}

Tuberculosis (TB) still represents a major public health problem in Brazil and arouses epidemiological interest from health authorities worldwide. Even after 30 years of implementation of the Millennium Development Goals (MDGs), assumed by member countries of the United Nations (UN), tuberculosis is the tenth cause of death in the world and, since 2007, it has been the first cause of death caused by a single infectious agent, overcoming HIV. In 2018, around 10.5 million people became ill from tuberculosis worldwide and 1.3 million people died from the disease (including 251 thousand co-infected with TB / HIV) $)^{(1-2)}$.

Despite the prevention and control measures adopted by health services, 72,788 new cases of tuberculosis in 2018 were reported in Brazil; and 4,534 thousand deaths from the disease in 2017. For the same year, 6,014 new cases were notified in the municipality of Rio de Janeiro ${ }^{(3)}$, with an incidence rate of 89.9/100 thousand inhabitants, higher than that in the country, of 34.8 / 100 thousand inhabitants ${ }^{(3-4)}$.

In order to control the transmission of tuberculosis in Brazil, the World Health Organization (WHO) launched the End TB Strategy (for the End of Tuberculosis), which proposes a radical change in the fight against TB and aims to end the global tuberculosis epidemic, with targets to reduce new cases by $90 \%$ and deaths from tuberculosis by $95 \%$ by $2035^{(5)}$.

Care centered on the patient / user and the support and support systems for those affected by TB are pillars of the End TB strategy, current tuberculosis control policy ${ }^{(5)}$. In this context, Directly Observed Treatment (DOT), one of the milestones of the Directly Observed Therapy Short-Course (DOTS) strategy, can contribute to greater adherence to treatment, especially among more vulnerable individuals ${ }^{(6)}$.

With the intention of controlling the transmission of the disease in Brazil, the National Program for the Control of Tuberculosis (NPCT), of the Ministry of Health, decentralized its actions of control, surveillance, prevention and treatment of the disease to Primary Health Care (PHC). This decentralization strategy increased access to treatment for populations at greater risk and vulnerability to contracting the disease, but did not significantly impact tuberculosis control indicators in the city of Rio de Janeiro ${ }^{(7)}$.

Despite the challenges for the implementation of the DOT by the Family Health teams, due to the organization of health services and the social context, there are improvements in the TB control indicators when implemented correctly ${ }^{(6,8-9)}$. Although the advances and the growing academic production related to DOT are recognized, it is possible to identify gaps regarding its applicability in different contexts ${ }^{(8-9)}$.

Such gaps are evidenced, above all, in the literature review, which points out criticisms due to the inability of this strategy to prevent the increase in the incidence of TB in locations with high prevalence. Only compliance with technical guidelines is insufficient to achieve success in controlling the disease, as the social, economic aspects and the context of the health services where the actions will be developed need to be considered ${ }^{(8-12)}$.

Despite the efforts of professionals to follow the recommendations of the DOT, there is a need to evaluate the implementation of the DOT in PHC units under national guidelines, reinforcing the activities of planning, supervision and evaluation of the actions offered at the first level of attention to healthcare. Considering that tuberculosis is a social disease, that is, the way people live and work influences illness and access to treatment, describing the functioning theory by modeling the two pillars of the DOTS strategy allows analyzing how these actions are being carried out by health professionals in PHC units in Rio de Janeiro ${ }^{(13-14)}$.

Several investigations take the DOT practice as an object of study, but do not discuss the quality of the effectiveness of this strategy and its influence on the work process ${ }^{(6,8-9)}$. In view of this, there is an understanding that the description of these elements through their modeling allows visualization of their functioning, avoiding errors in the evaluation process ${ }^{(14)}$. Logical models assist in the production of elements to the practice of management and care, in the identification of strengths and weaknesses in the process of carrying out the DOT and in the quality of information to support better and more accurate decisions in the area of health ${ }^{(15)}$.

The realization of this study is justified because there are, to date, no parameters that identify whether the directly observed treatment is implemented according to the rules of the World Health Organization and if the information reflects the health situation of the territory. In this way, the validation of logical models may contribute to base the strategic actions in Primary Care aiming to seek improvements in the work process and, in turn, in the quality of care offered to patients with tuberculosis.

Recognizing the magnitude of the DOTS Strategy and bearing in mind that there are gaps between theoretical knowledge and care practice, it was questioned: What resources and care should compose the Logical Model on Directly Observed Treatment and Information System (IS)? The logical models have valid content to be used by professionals of the Family Health Strategy (FHS) and managers of the Planning Area 2.1 (AP 2.1) of Rio de Janeiro?

\section{OBJECTIVES}

To describe the validation of the Logical Models (LM) of the Directly Observed Treatment and the Information System for the Primary Health Care units of the PA 2.1 in the city of Rio de Janeiro.

\section{METHODS}

\section{Ethical aspects}

The research was approved by the Research Ethics Committees of the Anna Nery School of Nursing at UFRJ and the Municipal Health Secretariat of Rio de Janeiro, for meeting the ethical and legal precepts of Resolution No. 466/2012 of the National Health Council, which deals with regulatory guidelines and standards for research involving human beings.

\section{Study design, period and location}

Methodological study, carried out from February to July 2018. The scenario was the PHC units in Planning Area 2.1 in the city of Rio de Janeiro. For the study design, this work used the recommendations of the Strengthening the Reporting of Observational Studies in Epidemiology Statement (STROBE) ${ }^{(16)}$. 
Given the need to choose parameters for the construction of logical models, the study was conducted in two stages: the first stage occurred from February to April 2018 with the search and selection of scientific evidence in the databases: Latin American Health Sciences Literature (LILACS), Scientific Electronic Library Online (SciELO) and Nursing Databases (BDENF). The health terminology consulted in the Health Sciences Descriptors (DeCS) and the descriptors "tuberculosis", "health evaluation", "program evaluation" and "Directly Observed Therapy" were used, in Portuguese and English, resulting in 135 publications, however only nine articles contributed to the modeling of the intervention.

Based on the literature review and documentary analysis, the first version of the Logical Models of the DOT and IS was elaborated, based on the proposal of the Centers for Disease Control (CDC), explaining the functioning and the steps necessary to transform the objectives in goals, for presentation to specialists $^{(12-15,17-18)}$. From the construction of the models, there was a need for their validation by specialists who operationalize and manage both the DOT and the IS in the city of Rio de Janeiro, so that they could identify the potentials, barriers and weaknesses of the instruments.

\section{Population, inclusion and exclusion criteria}

The second stage, validation of the logical models, took place from April to July 2018. In view of the diversity of references to determine the profile of the specialist, we chose to choose our own criteria based on the literature: master's degree in Family Health/Public Health and/or Sanitary Pulmonology; residency and/or specialization in Family Health/Public Health or Sanitary Pneumology; assistance practice of at least four years in the Family Health Strategy and/or tuberculosis in an outpatient setting; experience in $\mathrm{PHC}$ unit management; performance in the Tuberculosis Control Program, state or municipal. Experts were considered to be those who met four of the criteria described.

The first specialist was selected by the researcher due to the professional's prior knowledge, and the others were selected through Snowball sampling, in the which, when identifying a subject that fits the criteria for participation in the study, you are asked to suggest other participants ${ }^{(19)}$. The confirmation of the criteria for the classification of specialists was carried out through the analysis of the Curriculum Lattes. The contact took place via electronic mail, with the sending of an invitation letter; and, after acceptance, individual meetings were held between specialists and the researcher to present the study, read and sign the Free and Informed Consent Term (FICT) and the methodology used for the validation of LMs.

In order to establish consensus among experts regarding the validity of LMs, the Delphi technique was used, which consists of a group process whose objective is to obtain, compare and direct the judgment of specialists in order to obtain a convergence of responses from the participating subjects, with the intention of reaching a consensus that may represent the consolidation of the group's judgment ${ }^{(20)}$.

The final sample included eight specialists who worked in the State Tuberculosis Control Program (RJ), in the lato sensu graduate course in Sanitary Pulmonology at the Sérgio Arouca National School of Public Health (NSPH), at the Hélio Fraga Reference
Center and in the management of three family health units in the city of Rio de Janeiro.

\section{Study protocol}

After signing the FICT, the links to access the validation instruments for the Logical Model of the DOT and IS created by the authors on the Google Form platform were sent to the eight specialists via electronic mail. The validation instruments contained six pages, with the first two identifying the participant, clarifications about the validation of the instruments and instructions on how to complete them. The next four pages presented the operational components of the LMs for expert consideration.

The validation took place in two stages. In the first, the experts assessed the clarity, pertinence and relevance of the actions described for the two models, using a Likert scale whose response options varied in: A) strongly disagree, B) disagree, C) indifferent, D) totally agree and E) agree. In addition, below each operational component to be evaluated by the specialist, there was a field for recording your suggestions. A 10-day deadline for returning the duly completed instrument was established.

In the second stage, the experts evaluated the logical models in terms of semantics, understanding of the questions, writing and articulation between the items of each component. At that point, they were able to respond openly. When there was no return within the agreed deadline, electronic correspondence was sent reminding of the importance of participation and expected contribution in the study.

\section{Analysis of results and statistics}

For data organization and analysis, forms were saved in Microsoft Excel ${ }^{\circ} 2010$ spreadsheets and analyzed using descriptive statistics. The Content Validity Index (CVI) was calculated, which measures the proportion or percentage of experts who are in agreement on certain aspects of the instrument and its items. The CVI was calculated by dividing the number of concordant responses by the number of total responses in the instrument ${ }^{(19-21)}$.

Calculation of the CVI was performed for each of the items of the models and of the global CVI of the models. Due to the small number of specialists, the recommended in the literature was followed: items whose CVI presented results lower than 0.80 should be reviewed and / or eliminated from the models ${ }^{(21-22)}$. The participants' suggestions were also listed and categorized, resulting in the inclusion of new items and reformulation of others. Items with CVI greater than 0.80 were considered consensual by the specialists and underwent reassessment in the second and last round of validation.

\section{RESULTS}

Regarding the profile of the specialists, the majority were female $(n=7)$, and the average age was 36.3 years. The average training time was 12 years, with five years of experience in managing family health units $(n=3)$. Of the four specialists who worked in the $\mathrm{PHC}$, all had specialization in Family Health. Those who worked at the Hélio Fraga Reference Center and the State Tuberculosis 
Control Program had a specialization in Sanitary Pulmonology $(n=4)$. Three specialists had a professional master's degree in Family Health and two in Sanitary Pulmonology.

The preliminary version of the Logical Model of the DOT was composed of 46 items, and the $\mathrm{SI}$, of 39 items, which were grouped into five response items, one of which was neutral. Experts should respond by ticking only one option. Tables 1 and 2 show the items analyzed by the specialists, followed by the CVIs achieved.

In the first LM evaluation round, agreement was observed in most of the items described in the LMs, so that they underwent few changes. Of the 85 items evaluated by the experts, 15 did not reach the minimum CVI adopted in this study ${ }^{(21)}$, but the comments and suggestions of the experts were considered for the adjustment of these items, being 12 reformulated and two excluded from LMs.

Of the 46 items evaluated in the LM of the DOT, six were modified, and one item was excluded. In the item "Realization of RV", it was suggested not to use the acronym and the addition of the terms "by the CHA". For the item "\% of HV performed by patient", there was a question about its amplitude, being suggested "Number of home visits performed by CHAs". As tuberculosis notifications in the city of Rio de Janeiro are carried out on an online platform, it was suggested that the items "Update of the monitoring report" and "\% of notifications updated in the green book" be changed to "Update of notifications in the SINAN-RIO" and "\% of notifications updated in SINAN-RIO", respectively. Regarding the item "Number of absenteeism in the semester", the change to "\% of abandonment in the semester" was suggested. Finally, in the item "\% RMT, BAAR, Culture, ST, chest X-ray and PPD*, it was suggested to replace "\% of diagnostic and complementary exams performed". The item "printer" was evaluated by the specialists as not necessary for the performance of the DOT activities, being excluded from the LM.

As for the 35 items of the IS ML, seven were modified, and one item was excluded. With regard to the item "Cleaning the SINAN database", there was questioning about the performance of this activity by FHS professionals, with the suggestion "Analysis of data consistency". For the item "Updating and sending the follow-up bulletin", a replacement was suggested for "Updating data in ISs". Since not all Primary Care units in the city of Rio de Janeiro used the same electronic medical record at the time of this research, it was suggested that the item "Analysis of variables 1 and 3 of the electronic medical record" be changed to "Analysis of consultations in the electronic medical record".

In the item "\% of qualified records", it was suggested to replace the word "qualified" with "updated". There was a suggestion to modify the item "No. of patients computed in variable 3" to"No. of patients adequately monitored". Regarding the item "Professionals sensitized to the importance of notification and proper registration of cases", the change to "Professionals trained to register in information systems" was proposed. The experts suggested that the item "Improving the quality of filling out the notification form" be transferred to the operational component "Immediate result" and that the item "Epidemiological assessment of tuberculosis morbidity and mortality" be included in the "Intermediate result". Finally, the item "No. of new cases closed as a cure" was suggested to be excluded from the Logical Model.

In the first round of validation, the overall Content Validity Index for the DOT was 0.91 and the IS was 0.87. After all the corrections, the second version of the LMs was sent to the specialists for reassessment. Figures 1 and 2 represent the Logical Model of the validated DOT, with a global CVI of 0.93; and the Logical Model of the Information System validated, with a global CVI of 0.91 .

Table 1 - Validation of content of items in the Directly Observed Treatment, Logical Model by specialists, Rio de Janeiro, Rio de Janeiro, Brazil, 2018

\begin{tabular}{|c|c|c|}
\hline $\begin{array}{l}\text { Structural } \\
\text { component }\end{array}$ & $\begin{array}{l}\text { Items analyzed } \\
\text { Directly Observed Treatment }\end{array}$ & IVC \\
\hline \multirow[t]{14}{*}{ Input } & Human Resources & 1 \\
\hline & Standardization of conduct & 0.87 \\
\hline & Physical structure & 0.87 \\
\hline & Tuberculostatic drugs & 1 \\
\hline & Information system* & 1 \\
\hline & Computer & 0.87 \\
\hline & Internet & 1 \\
\hline & Printer & 0.62 \\
\hline & Refrigerator & 1 \\
\hline & Sputum pot & 1 \\
\hline & Rapid HIV** test & 1 \\
\hline & Electronic medical record & 0.87 \\
\hline & Green Book & 1 \\
\hline & Training of professionals in DOT*** & 0.87 \\
\hline \multirow[t]{12}{*}{ Activities } & Contacts evaluation & 1 \\
\hline & Direct observation of medication taking & 0.87 \\
\hline & Monthly consultations & 1 \\
\hline & Conducting home visits & 0.75 \\
\hline & Case notification at SINAN-RIO**** & 1 \\
\hline & Registration in the Green Book & 0.87 \\
\hline & Proper record in the electronic medical record & 0.87 \\
\hline & Follow-up bulletin update & 0.75 \\
\hline & Conducting active search for missing persons & 0.87 \\
\hline & Rapid HIV testing & 1 \\
\hline & Rapid Test Request, BAAR ${ }^{* * * * *}$, Culture, & 1 \\
\hline & TS $* * * * * *$, chest $\mathrm{X}$-ray and PPD ******** & 0.87 \\
\hline
\end{tabular}

Product No. of observations made during the attack 1 and maintenance phase

No. of consultations carried out

$\%$ of home visits made per patient

No. of cases notified at SINAN-RIO

No. of cases recorded in the Green Book

$\%$ of medical records with proper record

$\%$ of notifications updated in the Green Book $\quad 0.75$

Number of absentees in the semester $\quad 0.62$

$\%$ of contacts evaluated $\quad 0.87$

$\%$ of patients being treated with result of $\quad 1$ HIV-RT

$\%$ Rapid Test, BAAR, Culture, TS, chest radiography and PPD requested

Improvement in the technical capacity of

professionals for $\mathrm{TB}^{* * * * * * * * *}$ service

Immediate Improvement in the quality of information 1

result Reduced underreporting of TB cases

Practices for diagnosis and treatment of the $\quad 0.87$ appropriate disease

Reduction of treatment abandonment $\quad 1$

Intermediate Increased adherence to treatment 1

result Increased cure rate 1

Reduced incidence of tuberculosis $\quad 1$

Reduction of TB morbidity and mortality $\quad 1$

Note:** Information System: SINAN-RIO and Laboratory Environment Manager (LEM); ** Acquired Immunodeficiency Syndrome (HIV); *** Directly Observed Treatment (DOT); **** Notifiable Diseases Information System - Rio (SINAN-RIO); *****B Bacillus Acid Resistant Alcohol (BAAR); ${ }^{* * * * *}$ Sensitivity Test (TS); ${ }^{* * * * * * *}$ Purified Protein Derivative Molecular Rapid Test (PPD); ${ }^{* * * * * * *}$ Tuberculosis (TB). 
Table 2 - Content validation of the IS Logical Model items by specialists, Rio de Janeiro, Rio de Janeiro, Brazil, 2018

\begin{tabular}{|c|c|c|}
\hline $\begin{array}{l}\text { Structural } \\
\text { component }\end{array}$ & $\begin{array}{l}\text { Items analyzed } \\
\text { Information System }\end{array}$ & CVI \\
\hline \multirow[t]{10}{*}{ Input } & Human resources & 1 \\
\hline & Protocols & 0.87 \\
\hline & Physical structure & 0.87 \\
\hline & Greenbook & 1 \\
\hline & Notification Sheets & 0.87 \\
\hline & Computer & 0.87 \\
\hline & Internet & 1 \\
\hline & Printer & 0.87 \\
\hline & TB cases follow-up bulletin & 0.87 \\
\hline & Electronic medical record & 0.87 \\
\hline \multirow[t]{9}{*}{ Activities } & Training of professionals in IS * & 1 \\
\hline & Protocol for recording information & 0.87 \\
\hline & Cleaning the SINAN database & 0.62 \\
\hline & Registration of information in ISs * & 1 \\
\hline & Updating and sending the follow-up bulletin & 0.75 \\
\hline & $\begin{array}{l}\text { Timely closure of the case in the Information } \\
\text { Systems }\end{array}$ & 0.87 \\
\hline & Monthly monitoring of records in ISs & 0.87 \\
\hline & $\begin{array}{l}\text { Periodic verification of data completeness at } \\
\text { SINAN }\end{array}$ & 0.87 \\
\hline & $\begin{array}{l}\text { Analysis of variables } 1 * * \text { and } 3 * * * \text { of the } \\
\text { electronic medical record }\end{array}$ & 0.75 \\
\hline \multirow[t]{10}{*}{ Product } & No. of training courses & 0.87 \\
\hline & Protocol for recording the information prepared & 0.87 \\
\hline & $\%$ of qualified records & 0.87 \\
\hline & $\%$ TB cases registered in ISs & 0.87 \\
\hline & $\%$ notifications with updated information & 0.87 \\
\hline & No. of cases closed timely & 0.87 \\
\hline & Regularly monitored IS & 0.87 \\
\hline & $\%$ of notification forms with records in all fields & 0.87 \\
\hline & No. of new cases closed as a cure & 0.62 \\
\hline & No. of patients computed in variable 3 & 0.75 \\
\hline \multirow[t]{2}{*}{$\begin{array}{l}\text { Immediate } \\
\text { result }\end{array}$} & $\begin{array}{l}\text { Professionals aware of the importance of } \\
\text { notification and proper registration of cases }\end{array}$ & 0.75 \\
\hline & $\begin{array}{l}\text { Up-to-date and reliable information on the } \\
\text { treatment and status of the disease }\end{array}$ & 1 \\
\hline \multirow{2}{*}{$\begin{array}{l}\text { Intermediat } \\
\text { eresult }\end{array}$} & Reduction of underreporting & 1 \\
\hline & $\begin{array}{l}\text { Improving the quality of filling out the } \\
\text { notification form }\end{array}$ & 1 \\
\hline \multirow[t]{2}{*}{ Impact } & $\begin{array}{l}\text { Strengthening the actions of the Tuberculosis } \\
\text { Control Program }\end{array}$ & 1 \\
\hline & $\begin{array}{l}\text { Improvement in the analysis of the population's } \\
\text { health situation and in the evaluation of the } \\
\text { work developed in the } \mathrm{PA}^{*}\end{array}$ & 1 \\
\hline \multicolumn{3}{|c|}{$\begin{array}{l}\text { Note: *Information System (IS): SINAN-RIO, Electronic Health Record and Green Book; ** TB cure } \\
\text { rate; **** Follow-up of a person discharged for tuberculosis cure: A-Record the number of the SINAN } \\
\text { in the medical record for the accompanied patient; } B \text { - Have had at least } 5 \text { medical or nursing } \\
\text { consultations during the treatment period; C-To be discharged for curing tuberculosis registered } \\
\text { in the medical record and in SINAN; } D \text { - Record the result and at least two sputum smears; E- Have } \\
\text { a record of the results of an HIV test until the } 2 \text { nd month of treatment; } F \text { - Have an evaluation } \\
\text { record of all contacts; G - Have received at least } 12 \text { visits from the CHA; ***** Planning Area. }\end{array}$} \\
\hline
\end{tabular}

\section{DISCUSSION}

The construction of the LM of the DOT and the IS helped to identify the relationships of inputs, program activities and expected effects with the perspective of enhancing these actions within the scope of health units. The identification of structural components was based on the objectives of the TCP, following the chain that the right resources will be transformed into necessary actions for the population, and this, in a favorable context, will lead to the results that the program intends to achieve ${ }^{(17,22)}$.

In the results found, it was found that the proposed methodology made it possible to obtain a consensus of experts to validate the suggested models. The percentage of agreement found was higher than the established minimum of 0.80 , also used in the validation of an instrument for analyzing the performance of $\mathrm{PHC}$ services ${ }^{(23)}$ and in a study carried out to validate a model of care for people with tuberculosis and their social network ${ }^{(24)}$. In the health field, several researches were conducted with the intention of performing the intervention modeling to define what should be evaluated, as the visual representation expresses the program's theory of operation to achieve the proposed objectives ${ }^{(8,24-26)}$.

The incorporation of stakeholders to validate the models made it possible to describe more precisely some activities. In the logical model of the DOT, in the Assistance component, activities specific to the TCP were identified, such as: home visits, monthly follow-up consultation, with weight verification, and activities aimed at training new professionals such as continuing education. In fact, permanent and/or continuing education actions are important in view of the need for assistance services to constitute a space for reflective action for the permanent evaluation of the stages of the implementation of the DOTS Strategy. However, for the sustainability of this strategy, it is essential that there are professionals capable of establishing a bond with the patient and carrying out the clinical management of the disease in an appropriate manner, reducing dropout rates ${ }^{(27)}$.

As for the Epidemiological Surveillance component, it was observed that the participation of specialists contributed to the expansion of the scope of the actions listed in the first version. Activities have a broader focus than just encouraging active search for tuberculosis cases. They include, for example, the monitoring of tuberculosis indicators, analysis of information generated by the team, in addition to active search, notification and updating of current information systems ${ }^{(25)}$.

In the Laboratory Support component, part of the specialists prioritized the diagnosis based on the performance of sputum smear microscopy or the Rapid Molecular Test, implanted in Rio de Janeiro since $2014^{(28-29)}$. In the municipality, universal sputum culture is recommended, being carried out in all positive BAAR or RMT samples; the sensitivity test should be requested when there is suspicion of tuberculosis resistant to one or more drugs. Universal testing for the human immunodeficiency virus (HIV) in all tuberculosis patients is also recommended ${ }^{(29)}$.

Regarding the logical model of the SI, with regard to the Management and Monitoring component, it consists of activities focused on the management and monitoring of the information available in the electronic medical record, in the Notifiable Diseases Information System (SINAN) and in the Registration and Monitoring of Treatment of Tuberculosis Cases (Green Book). In the municipality, user data are recorded in an electronic medical record and evaluated every quarter for quality. To receive the financial incentive for variable 3,"Monitoring a person discharged for tuberculosis cure", professionals must register in the specific fields of the medical record the five indicators related to this variable ${ }^{(30)}$. The description of such actions and their effects in the short, medium and long term have been refined together with 


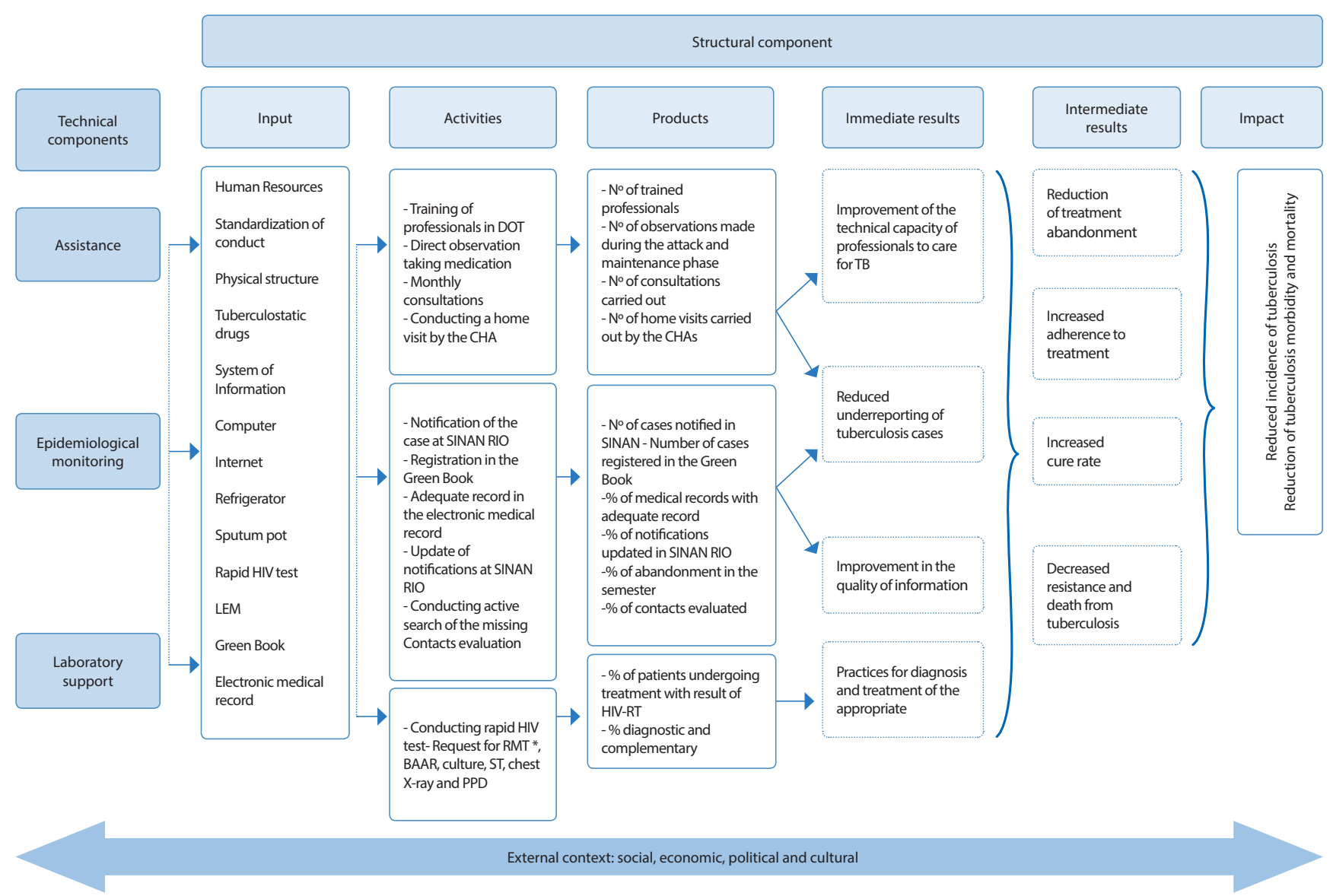

Figure 1 - Validated version of the Logical Model of Directly Observed Treatment, Rio de Janeiro, Rio de Janeiro, Brazil, 2018

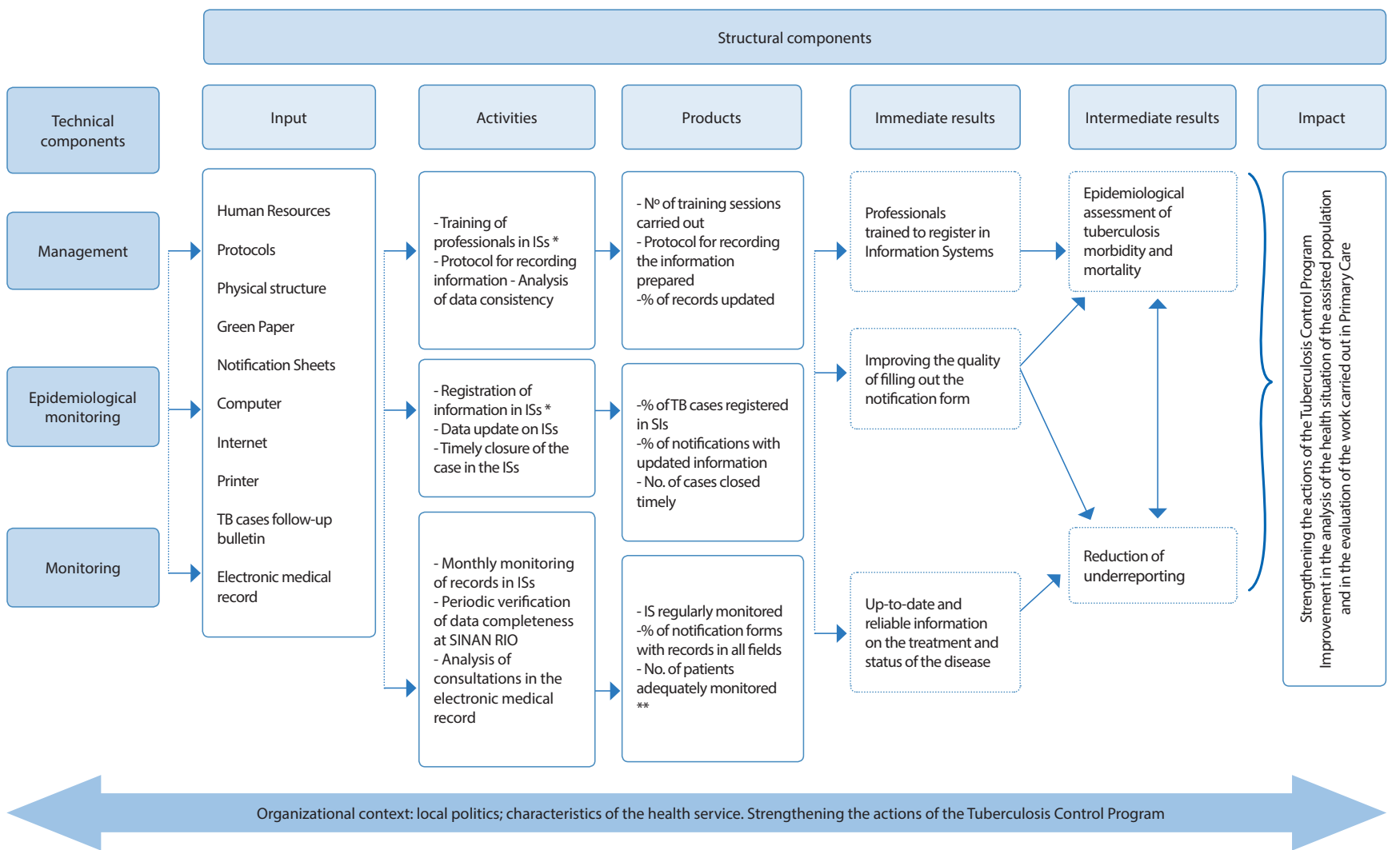

Figure 2 - Validated version of the Logical Model of the Information System, Rio de Janeiro, Rio de Janeiro, Brazil, 2018 
the experts, as they can favor the reorientation of the professionals' actions with a view to both the integrality of the assistance provided to the user, the family and the community as well as the effectiveness of the program with the target population ${ }^{(25-27)}$.

The shared description of the DOT and IS intervention together with the specialists aimed to involve them in the evaluation process. For this, it is important that the intervention makes sense to these stakeholders and that the assessment is responsive to their interests and needs. The incorporation of different stakeholders in the evaluation process is considered a way to increase the relevance and incorporation of future results, as well as the use of evaluation ${ }^{(15)}$.

\section{Study limitations}

As a limitation of the study, it is noteworthy that, despite the logical models having been evaluated for content validity by experts, at the time of the research, statistical tests had not been used to verify its reliability. Another important limitation refers to the generalization of the findings, considering that the research was carried out in only one planning area in the city of Rio de Janeiro.

\section{Contributions to the area of Nursing, Health or Public Policy}

The validated logical models are configured as a contribution for TCP managers and nurses who work in support of people with tuberculosis, as they allow to expand the knowledge about the DOT intervention and the practices adopted, as well as to monitor performance and performance and progress of the intervention. This study gains relevance by offering foundations for the improvement of the DOT as a TB and IS control action for the analysis and monitoring of the population's health conditions, constituting itself as a trigger for the evaluation and planning of actions in the scope of assistance and management.

\section{CONCLUSIONS}

The study achieved the proposed objective regarding the construction and validation of the LMs of the Directly Observed Treatment and the Information System. The Content Validity Index reached the values considered adequate, making the material produced valid.

Validated logical models can contribute to improving the quality of care provided to tuberculosis patients, being useful and timely instruments to support managers in decision-making, as they allow for monitoring treatment actions in accordance with current legislation.

It is suggested, however, that further studies be carried out in order to evaluate the replication of these models in the other planning areas of the municipality, as well as to verify the reliability of LMs.

\section{ACKNOWLEDGMENT}

Thanks to the Planning Area Coordination 2.1 for accepting the development of research in the area; and professionals for participating in the research.

\section{REFERENCES}

1. Roma JC. Os objetivos de desenvolvimento do milênio e sua transição para os objetivos de desenvolvimento sustentável. Cienc Cult [Internet]. 2019 [cited 2020 Mar 02];71(1):33-39. Doi: 10.21800/2317-66602019000100011

2. World Health Organization (WHO). Global Tuberculosis Report 2019 [Internet]. 2019 [cited 2019 Nov 16]. Available from: https://www.who. int/tb/publications/global_report/en/

3. Ministério da Saúde (BR). Secretaria de Vigilância em Saúde. Boletim epidemiológico. Brasil Livre da Tuberculose: evolução dos cenários epidemiológicos e operacionais da doença [Internet].2019 [cited 2019 Sep 20] 50(9):1-18. Available from: https://portalarquivos2.saude.gov br/images/pdf/2019/marco/22/2019-009.pdf

4. Governo do Estado do Rio de Janeiro. Coordenação de Doenças Transmissíveis. Boletim epidemiológico coordenação de doenças transmissíveis: HIV, Tuberculose e Hanseníase. Rio de Janeiro [Internet]. 2018. [cited 2018 Sep 20]. Available from: http://www.rio.rj.gov.br/ dlstatic/10112/123737/DLFE-1767.pdf/1.0

5. Ministério da Saúde (BR). Secretaria de Vigilância em Saúde. Plano Nacional Pelo Fim da Tuberculose como Problema de Saúde Pública[Internet]. Brasília: Ministério da Saúde; 2017 [cited 2019 Sep 20]:1-54. Available rom: http://bvsms.saude.gov.br/bvs/publicacoes/ brasil_livre_tuberculose_plano_nacional.pdf

6. Orlandi GM, Pereira EG, Biagolin REM, França FOS, Bertolozzi MR. Social incentives for adherence to tuberculosis treatment. Rev Bras Enferm [Internet]. 2019 [cited 2020 Mar 02];72(5):1182-8. doi. 10.1590/0034-7167-2017-0654

7. Ministério da Saúde (BR). Secretaria de Vigilância em Saúde. Manual de recomendações para o controle da tuberculose no Brasil. 2a.ed. Brasília; 2019. 366p.

8. Lavôr DCBS, Pinheiro JS, Gonçalves MJF. Evaluation of the implementation of the directly observed treatment strategy for tuberculosis in a large city. Rev Esc Enferm USP[Internet]. 2016 [cited 2019 Sep 13];50(2):245-52. doi.10.1590/S0080-623420160000200010

9. Chuck C. Enhancing management of tuberculosis treatment with video directly observed therapy in New York City. Int J Tuberc Lung Dis [Internet]. 2016 [cited 2019 Sep 15];20(5):588-93. Available from: https://www.ncbi.nlm.nih.gov/pubmed/27084810.

10. Shuhama BV, Silva LMC, Andrade RLP, Palha PF, Hino P, Souza KMJ. Evaluation of the directly observed therapy for treating tuberculosis according to the dimensions of policy transfer. Rev Esc Enferm USP [Internet]. 2017 [cited 2020 Mar 09];51:e03275. doi.10.1590/ s1980-220x2016050703275 
11. Dobler CC. Sucecess of communit-based directly observed anti-tuberculosis in Mongolia. Int J Tuberc Lung Dis [Internet]. 2015 [cited 2019 Sep 13];19(6):657-662. Available from: https://espace.curtin.edu.au/bitstream/handle/20.500.11937/53747/252617. pdf?sequence $=2$ \&isAllowed $=y$

12. Joseph MR. Directly observed treatment short course for tuberculosis. What happens to them in the long term? Indian J Tuberc [Internet]. 2015[cited 2019 Oct 09];62(1):29-35. Available from: http://www.ncbi.nlm.nih.gov/pubmed/25857563

13. Reis-Santos B, Pellacani-Posses I, Macedo LR, Golub JE, Riley LW, Maciel EL. Directly observed therapy of tuberculosis in Brazil: associated determinants and impact on treatment outcome. Int J Tuberc Lung Dis [Internet]. 2015 [cited 2019 Sep 20];19(10):1188-93. doi: 10.5588/ ijtld.14.0776

14. Bezerra CAB, Cazarin G, Alvez CKA. Modelagem de Programas: da teoria à operacionalização. In: Samico I. Avaliação em Saúde: Bases conceituais e operacionais. Rio de Janeiro: Medbook, 2010. p. 65-78.

15. Cardoso GCP, Oliveira EA, Casanova AO, Toledo PPS, Santos EM. Participação dos atores na avaliação do Projeto QualiSUS-Rede: reflexões sobre uma experiência de abordagem colaborativa. Saúde Debate [Internet]. 2019[cited 2019 Nov 05];43(120):54-68. doi.10.1590/0103-1104201912004

16. Pacheco RL, Martimbianco ALC, Garcia CM, Logullo P, Rieral R. Guidelines para publicação de estudos científicos. Parte 2: Como publicar estudos observacionais (coorte, caso-controle e transversal). Diagn Tratam [Internet]. 2017 [cited 2020 May 25];22(3):121-6. Available from: http://docs.bvsalud.org/biblioref/2017/08/848018/rdt_v22n3_121-126.pdf

17. Araujo RF, Costa JMBS, Cruz MM, França JRM. Avaliabilidade da compatibilização de indicadores e metas dos instrumentos de planejamento do Ministério da Saúde. Saúde Debate [Internet]. 2018 [cited 2019 Sep 14];42(118):566-78. doi: 10.1590/0103-1104201811802

18. Centers for Disease Control and Prevention (CDC). Framework for Program Evaluation in Public Health. MMWR [Internet] 1999 [cited 201914 Set];48(No. RR-11):1-58. Available from: https://www.cdc.gov/mmwr/PDF/rr/rr4811.pdf

19. Polit DF, Beck CT. Fundamentos de Pesquisa em enfermagem: avaliação de evidências para as práticas da enfermagem. 7th ed. Porto Alegre: Artmed; 2011.

20. Pereira RDM, Alvim NA. Técnica Delphi no diálogo com enfermeiros sobre a acupuntura como proposta de intervenção de enfermagem. Esc Anna Nery [Internet]. 2015 [cited 2019 Sep 14];19(1):174-80. doi: 10.5935/1414-8145.20150024

21. Souza AC de, Alexandre NMC, Guirardello EB. Propriedades psicométricas na avaliação de instrumentos: avaliação da confiabilidade e da validade. Epidemiol. Serv Saúde [Internet]. 2017 [cited 2019 Sep 14];26(3):649-59. doi: 10.5123/s1679-49742017000300022

22. Coluci MZO, Alexandre NMC, Milani MD. Construção de instrumentos de medida na área da saúde. Ciênc Saúde Coletiva [Internet]. 2015 [cited 2019 Sep 14];20(3):925-36. doi: 10.1590/1413-81232015203.04332013

23. Barreira D. Os desafios para a eliminação da tuberculose no Brasil. Epidemiol Serv Saude [Internet] 2018 [cited 2019 Sep 14];27(1):e00100009. doi: 10.5123/S1679-49742018000100009

24. Cubas MR, Faoro NT, Moysés ST, Carvalho DR. Avaliação da Atenção Primária à Saúde: validação de instrumento para análise de desempenho dos serviços. Saúde Debate [Internet]. 2017 [cited 2019 Sep 14];41(113):471-485.doi: 10.1590/0103-1104201711310

25. Souza SS, Palha PF. Modelo de cuidado de las personas contuberculosis y lared social: um estudio metodológico. Enferm Comun[Internet]. 2019 [cited 2019 Sep 14];15. Available from: http://ciberindex.com/c/ec/e12385

26. Soares BC, Cardoso GCP, Figueiró AC. Análise estratégica da Vigilância Epidemiológica em tuberculose: uma experiência local. Saúde Debate [Internet]. 2017 [cited 2019 Sep 14];41(spe ):22-33. doi:10.1590/0103-11042017s03

27. Andrade HS, Oliveira VC, Gontijo TL, Pessôa MTC, Guimarães EAA. Avaliação do Programa de Controle da Tuberculose: um estudo de caso. Saúde Debate [Internet]. 2017 [cited 2019 Sep 14];41(spe):242-58. doi: 10.1590/0103-11042017s18

28. Clementino FS, Marcolino EC, Gomes LB, Guerreiro JV, Miranda FAN. Ações de controle da tuberculose: análise a partir do programa de melhoria do acesso e da qualidade da atenção básica. Texto Contexto Enferm [Internet]. 2016 [cited 2019 Sep 14];25(4):e4660015. doi: 10.1590/0104-07072016004660015

29. Lima TM, Belotti NCU, Nardi SMT, Pedro HSP. Teste rápido molecular GeneXpert MTB/RIF para diagnóstico da tuberculose. Rev Pan-Amaz Saude [Internet]. 2017[cited2019 Sep 14];8(2):65-76. doi: 10.5123/s2176-62232017000200008

30. Poli NP, Faoro Nilza T, Prado Jr JC, Pisco LAC. Remuneração variável na Atenção Primária à Saúde: relato das experiências de Curitiba e Rio de Janeiro, no Brasil, e de Lisboa, em Portugal. Ciên Saúde Coletiva [Internet]. 2016 [cited 2019 Sep 14];21(5):1377-88. Doi:10.1590/1413-81232015215.02212016 